\title{
THE EFFECT OF STOCKING DENSITY ON INDIVIDUAL BROILER WELFARE PARAMETERS 2. DIFFERENT BROILER STOCKING DENSITIES
}

\author{
Z. Škrbićc $^{1}$, Z. Pavlovski ${ }^{1}$, M. Lukić ${ }^{1}$, V. Petričević ${ }^{1}$, M. Đukić-Stojčić ${ }^{2}$, \\ D. Žikić ${ }^{2}$
}

\author{
${ }^{1}$ Institute for Animal Husbandry, Autoput 16, P. Box 23, 11080, Belgrade-Zemun, Republic of Serbia \\ ${ }^{2}$ Agriculture faculty, 21000, Novi Sad, Republic of Serbia \\ Corresponding author: zdskrbic@gmail.com \\ Original scientific paper
}

\begin{abstract}
Stocking density is considered one of the most important factors for the welfare of broilers. This paper is continuation of the study in order to obtain full evaluation of the impact of different broiler stocking densities on production performance, condition of the broiler legs and body feathering, as welfare indicators but also indicators of the productivity and quality of produced chickens. The effect of three stocking densities $\left(20,15\right.$ and $\left.10 \mathrm{birds} / \mathrm{m}^{2}\right)$ was investigated in 4 repetitions on broilers of genotype Hubbard at the age of 3 and 6 weeks. At the age of 6 weeks stocking density of 20 birds $/ \mathrm{m}^{2}$ resulted in significantly lower growth of broilers, higher mortality and higher incidence of leg lesions and problems with body feathering, compared to stocking densities of 15 and $10 \mathrm{birds} / \mathrm{m}^{2}$.
\end{abstract}

Key words: broilers, stocking density, welfare

\section{Introduction}

The dependance of the product quality from the state of animal welfare (Sundrum, 2001), as well as legislation at European (Council Directive 2007/43/EC) and national level (Law on animal welfare), cause the introduction of certain changes/corrections into process of broiler production.

Welfare of farm animals is estimated through combination of physical and social indicators. In general, minimal mortality, low level of diseases and lesions, good body conditions, possibility for exhibition of main forms of behaviour and social connections, absence of physiological signs of stress, indicate absence of problems associated with welfare (Broom, 1991). Also, production results, in addition to their importance from the aspect of economical efficiency of production, are also important in estimation of welfare.

Broiler welfare is under the influence of numerous environmental factors which are mainly determined by the production management (Hristov et al., 2006). 
Quality of air (temperature, relative humidity, gases, contamination), quality of litter/bedding (humidity, temperature, structure), light (photoperiod, intensity) and stocking density are the most important factors of the environment.

Stocking density exhibits direct and indirect influence on broiler welfare. High stocking density has direct influence of broiler welfare by physical restriction of their movement which reflects on development of locomotive apparatus and exhibition of main forms of broiler behaviour. Indirect effects are associated with the quality of air and litter/bedding and effect on incidence of diseases, condition of legs and body feathering (lesions, blister, dermatitis).

This paper is continuation of the study in order to obtain full evaluation of the impact of different broiler stocking densities on production performance, condition of the broiler legs and body feathering, as welfare indicators but also indicators of the productivity and quality of produced chickens. Obtained results (Škrbic et al., 2009) indicated presence of certain tendencies of deterioration of investigated welfare indicators, presented through higher frequency of lower scores with the increase of stocking density of housed broilers $\left(10,13,16 \mathrm{birds} / \mathrm{m}^{2}\right)$. Considering that methods used for evaluation of welfare indicators are subjective, we find that in order to objectivelly evaluate in general the effect of stocking density on broiler welfare it is necessary to acquire more scientifically based results.

\section{Materials and Methods}

Trial was carried out during spring season, in production facility with floor system of rearing and controled environment conditions. Total of 1380 one day old chickens of Hubbard genotype were placed into boxes in 3 stocking densities (A:20 birds $/ \mathrm{m}^{2}$; B: 15 birds $/ \mathrm{m}^{2}$; C: 10 birds $/ \mathrm{m}^{2}$ ) and 4 repetitions. Chopped straw was used as litter/bedding. Continuous light regime 23L:1D was implemented. All chickens had the same adequate space where they received food and water. Nutrition was ad libitum with 4 mixtures, formulated based on corn/soy bean.

Control of the body weight of broilers and evaluation of welfare parameters were done at the age of 3 and 6 weeks on a sample of 50 chickens per box, i.e. 200 chickens per treatment. Mortality and feed conversion were calculated for whole fattening period. The locomotion ability was evaluated according to the method of Kestin et al. (1992). Gait score marks six categories relating to locomotion ability ranked from 0 (completely normal) to 5 (immobile), described in the paper by Thomas et al. (2004). In the same paper also the method is described based on which hock burns in chickens were determined: score $1=$ no burns; score 2 = mild burns; score 3 = severe burns. Featheringof chickens was evaluated according to method of Gyles et al. (1962) modified to changes in body weight and breast width of modern broiler hybrids (Perić et al., 2007). Foot pad 
lesions were scored using the three point scale (Thomas et al., 2004): score $1=$ no lesions; score 2 = mild lesions; score 3 = severe lesions.

In order to determine the qualitty of litter, on 21 st and 42 nd day temperature of litter was measured on 5 locations/points in the box, and in this way average litter temperature was obtained per box as trial unit. At the end of trial, in the same way litter samples were taken to determine the misture content by method of drying of samples at the temperature of $105^{\circ} \mathrm{C}$ until they reach constant weight.

Data was analyzed by method of variance analysis and Tukey test (Stat.Soft,Inc. STATISTICA, version 6). In addition to average values, analysis also included frequency of the welfare indicator scores Pin trial groups. Percentage data were converted to arcsine prior to analyses.

\section{Results and Discussion}

General tendency of decrease of body weight with the increase of stocking density was confirmed by average body weightes obtained at the end of the sixth week of age of broilers (table 1). In the third week, the positive effect of higher stocking density on growth rate was registered, through increased generating of metablic energy in groups with more chickens in the box, and the ability of chickens, in this stage, to utilize it for more intensive growth (Dozier et al., 2005).

In the group with the highest stocking density the mortality of chickens was the highest $(6.67 \%)$. In conditions of equal and constant feeding space, as a response to increase of stocking density, the consumption of food is reduced (Cravener et al., 1992). Depression in food consumption was greater in relation to reduction of body weight increase, so that ultimately we have better feed conversion in higher stocking densities (Škrbić, 2007).

Table 1. Production parameters of chickens housed in studied stocking densities at the age of 3 and 6 weeks

\begin{tabular}{|c|c|c|c|}
\hline \multirow{2}{*}{ Parameter } & \multicolumn{3}{|c|}{ T R E A T M E N T } \\
\cline { 2 - 4 } & $\mathrm{A}$ & $\mathrm{B}$ & $\mathrm{C}$ \\
\hline $\mathrm{n}$ & 200 & 3 weeks & 200 \\
\hline Body weight, $\mathrm{g}$ & $733.9 \pm 90.4$ & $717.3 \pm 100.6$ & $712.7 \pm 88.8$ \\
\hline & & & 6 weeks \\
\hline $\mathrm{n}$ & & 200 & 200 \\
\hline & 200 & $2404.5 \pm 327.2^{\mathrm{A}}$ & $2441.5 \pm 322.5^{\mathrm{A}}$ \\
\hline Body weight, $\mathrm{g}$ & $2307.5 \pm 304.5^{\mathrm{B}}$ & 3.91 & 3.75 \\
\hline Mortality, \% & 6.67 & 1.86 & 2.13 \\
\hline Feed conversion, $\mathrm{kg}$ & 1.92 & & \\
\hline & & & \\
\hline
\end{tabular}

A-B $p<0.01$ 
Average scores of welfare indicators, presented in table 2, are very high, with small differences between groups but certain detioration observed in the group with the highest stocking density and in the function of time, i.e. age of chickens. It is difficult to give adequate assessment of the welfare condition in studied stocking densities on that basis alone. Therefore, in subsequent tables $(3,5,6)$ frequencies of welfare indicator scores according to groups and age of broilers are presented.

Table 2. Average scores of welfare indicators at the age of chickens of 3 and 6 weeks

\begin{tabular}{|l|c|c|c|c|c|}
\hline Treatment & $\mathrm{n}$ & Gait score & Foot pad & Hock burns & Feathering \\
\hline \multicolumn{5}{|c|}{3 weeks } \\
\hline A & 200 & 0.04 & 1.08 & 1.01 & 2.34 \\
\hline B & 200 & 0.04 & 1.04 & 1.00 & 2.18 \\
\hline C & 200 & 0.04 & 1.04 & 1.00 & 2.14 \\
\hline \multicolumn{7}{|l|}{6 weeks } \\
\hline A & 200 & 0.25 & 1.21 & 1.37 & 1.21 \\
\hline B & 200 & 0.08 & 1.12 & 1.27 & 1.13 \\
\hline C & 200 & 0.16 & 1.00 & 1.18 & 1.07 \\
\hline
\end{tabular}

If we accept the criteria of Kestin et al. (1992) that chicken welfare is severly compromised when gair score is 3 and above, we can conclude that welfare situation in all three groups of chickens at the age of 3 weeks was not disturbed. At the age of chickens of 6 weeks, $0.61 \%$ of evaluated chickens had score 3 and $0.61 \%$ score 5 , which indicates severly disturbed welfare, considering that chickens in such conditions experience pain and discomfort and/or are immobile which compromises the fullfilment of their basic needs for food and water. However, also in group $\mathrm{C}, 1.44 \%$ chickens were scored 3 . Cause for this is probably significantly higher body weight of chickens which leads to physical inactivity regardless of the available space for movement.

Table 3. Impact of stocking density on the gait score of broilers at 3 and 6 weeks of age

\begin{tabular}{|c|c|c|c|c|c|c|c|c|c|c|c|c|}
\hline \multirow{2}{*}{ Treatment } & \multicolumn{6}{|c|}{3 weeks } & \multicolumn{6}{|c|}{6 weeks } \\
\hline & 0 & 1 & 2 & $\overline{3}$ & 4 & 5 & 0 & 1 & 2 & 3 & 4 & 5 \\
\hline & & & & & & & & & & & & - \\
\hline $\begin{array}{c}\text { Stocking } \\
\text { density }\end{array}$ & NS & NS & NS & NS & NS & NS & NS & * & NS & NS & NS & NS \\
\hline A & 96.0 & 4.0 & 0 & 0 & 0 & 0 & 83.43 & 10.43 & 4.91 & 0.61 & 0 & 0.61 \\
\hline B & 97.0 & 2.5 & 0.5 & 0 & 0 & 0 & 94.28 & 3.57 & 2.14 & 0 & 0 & 0 \\
\hline $\mathrm{C}$ & 96.0 & 4.0 & 0 & 0 & 0 & 0 & 90.65 & 3.60 & 4.32 & 1.44 & 0 & 0 \\
\hline
\end{tabular}


In order to better understand the frequency of incidence of foot pad lesions and hock burns, it is necessary to analyze the changes in the quality of litter with the increase of stocking density (table 4). Stocking density affects the humidity and temperature of the litter/bedding, in a way that they increase with the increase of stocking density which is in accordance with the results of Mendes et al. (2004), Dozier et al. (2006), Škrbić et al. (2009). Quality of litter/bedding directly affects the condition and health of skin of chickens, moist and coarse litter is high risk for incidence of lesions and contact dermatitis.

Table 4. Average temperature and humidity of litter in studied broiler stocking densities

\begin{tabular}{|c|c|c|c|}
\hline \multirow{2}{*}{ Treatment } & \multicolumn{2}{|c|}{ Average temperature, ${ }^{\circ} \mathrm{C}$} & $\begin{array}{c}\text { Average contain humidity (\%) } \\
\text { in 6 week }\end{array}$ \\
\cline { 2 - 3 } & 3 weeks & 6 weeks & \\
\hline & & & 51.55 \\
\hline $\mathrm{A}$ & 26.69 & 32.96 & 51.35 \\
\hline $\mathrm{B}$ & 25.19 & 29.37 & 49.96 \\
\hline $\mathrm{C}$ & 23.75 & 27.52 & \multicolumn{2}{|c|}{} \\
\hline
\end{tabular}

In stocking density of $20 \mathrm{birds} / \mathrm{m}^{2}$ determined frequncy of incidence of medium severe foot pad lesions was highly significantly higher compared to stocking density of $10 \mathrm{birds} / \mathrm{m}^{2}$. Accordingly, frequency of scores for hock burns were similar, but without statistical significance between esteblished differences (table 5). This effect was not present in previous study (Škrbić et al., 2009) which indicates the significance of commitment to a certain stocking density, but also significance of factors within the facility, primarily air humidity which, in conditions of high stocking density, inadequate air circulation and high outside humidity, also increases and has adverse effect on quality of litter and at the same time on incidence of foot pad dermatitis and hock burns. Elwinger (1995) defines them as factors of the farm and points out the importance of the season in determination of the optimal broiler stocking density.

Good feathering provides for broilers protection from injuries and negative influences from the environment, including low temperatures. Proces of forming of featheringis determined by genetic, but also hormonal status of the organism which is under significant influence of the environment and nutrition (Leeson and Walsh, 2004). With the increase of stocking density the featheringof broilers at the age of 6 weeks was of poorer quality (table 6). Differences in frequency of scores 1 and 2 were more expressed between groups $\mathrm{A}$ and $\mathrm{C}(\mathrm{p}=0.068)$. Also, in group $\mathrm{A}, 2.45 \%$ of evaluated broilers had relatively great areas of skin not covered with feathers, whereas in groups B and C, there were no broilers with such scores. 
Table 5. Impact stocking density on the incidence of foot pad lesions and hock burns of broilers at 3 and 6 weeks of age

\begin{tabular}{|c|c|c|c|c|c|c|}
\hline \multirow{2}{*}{ Treatment } & \multicolumn{3}{|c|}{3 weeks } & \multicolumn{3}{|c|}{6 weeks } \\
\hline & 1 & 2 & 3 & 1 & 2 & 3 \\
\hline \multicolumn{7}{|c|}{ Foot pad lesions } \\
\hline Stocking density & NS & NS & NS & $* *$ & $* *$ & NS \\
\hline A & 91.50 & 8.50 & 0 & $79.45^{\mathrm{bB}}$ & $20.55^{\mathrm{bB}}$ & 0 \\
\hline $\mathrm{B}$ & 96.50 & 3.50 & 0 & $87.50^{\mathrm{bAB}}$ & $12.50^{\mathrm{bAB}}$ & 0 \\
\hline $\mathrm{C}$ & 96.00 & 4.00 & 0 & $100^{\mathrm{a} A}$ & $0^{\mathrm{aA}}$ & 0 \\
\hline \multicolumn{7}{|c|}{ Hock burns $\quad-\%-$} \\
\hline Stocking density & NS & NS & NS & NS & NS & NS \\
\hline A & 98.50 & 1.50 & 0 & 64.42 & 34.31 & 1.27 \\
\hline B & 99.50 & 0.50 & 0 & 73.21 & 26.08 & 0.71 \\
\hline $\mathrm{C}$ & 100 & 0 & 0 & 81.65 & 18.35 & 0 \\
\hline
\end{tabular}

${ }^{* *} \mathrm{p}<0.01 ; \quad \mathrm{a}-\mathrm{b} \quad \mathrm{p}<0.05 ; \quad$ A-B $\mathrm{p}<0.01$

Table 6. Effect of stocking density on feathering in broilers at 3 and 6 weeks of age

\begin{tabular}{|c|c|c|c|c|c|c|}
\hline \multirow{2}{*}{ Treatment } & \multicolumn{3}{|c|}{ 3 weeks } & \multicolumn{3}{c|}{ 6 weeks } \\
\cline { 2 - 8 } & 1 & 2 & 3 & 1 & 2 & 3 \\
\hline \multicolumn{7}{|c|}{$\%$} \\
\hline Stocking density & NS & NS & NS & NS & NS & NS \\
\hline A & 12.50 & 42.50 & 45.00 & 80.99 & 16.56 & 2.45 \\
\hline B & 16.00 & 46.50 & 37.50 & 87.15 & 12.85 & 0 \\
\hline C & 19.00 & 46.00 & 35.00 & 93.17 & 6.83 & 0 \\
\hline
\end{tabular}

\section{Conclusion}

Stocking density, based on investigated indicators, cannot be considered a factor which influences broiler welfare at the age of 3 weeks. The assessment of locomotion ability based on gait score indicated that the best results can be achieved in conditions of "moderate" stocking densities (B group), considering that in this way the inactivity of broilers caused by lack of space, i.e. high body weights, is avoided.

Stocking density of $20 \mathrm{birds} / \mathrm{m}^{2}$ leads to significantly lower growth of broilers, higher mortality and higher frequency of incidence of leg lesions and 
problems with body fethering, compared to stocking densities of 15 and 10 $\operatorname{birds} / \mathrm{m}^{2}$.

\title{
Acknowledgment
}

This research is part of the Project EVB: TP-31033 financial supported by Ministry of Science and Technological Development of the Republic of Serbia.

\section{Uticaj gustine naseljenosti na pojedine parametre dobrobiti brojlera 2. različite gustine naseljenosti brojlera}

\author{
Z. Škrbić, Z. Pavlovski, M. Lukić, V. Petričević, M. Đukić-Stojčić, D. Žikić
}

\section{Rezime}

Gustina naseljenosti se smatra jednim od važnijih faktora za dobrobit brojlera. Rad predstavlja nastavak istraživanja u cilju potpunijeg sagledavanja efekata različitih gustina naseljenosti brojlera na proizvodne performanse, stanje nogu i telesnog pokrivača, kao indikatore dobrobiti ali i proizvodnosti i kvaliteta proizvedenih pilića. Ispitan je uticaj tri gustine naseljenosti $\left(20,15 \mathrm{i} 10 \mathrm{grla} / \mathrm{m}^{2}\right) \mathrm{u}$ 4 ponavljanja na brojlerima genotipa Hubbard u uzrastu 3 i 6 nedelja. Gustina naseljenosti se, na osnovu ispitanih indikatora, ne može smatrati faktorom koji utiče na dobrobit pilića u uzrastu od 3 nedelje. U uzrastu od 6 nedelja gustina naseljenosti od $20 \mathrm{grla} / \mathrm{m}^{2}$ je rezultirala značajno manjim porastom brojlera, većim mortalitetom i većom frekvencijom pojavljivanja problema sa nogama i telesnim pokrivačem u odnosu na gustine od 15 i $10 \mathrm{grla} / \mathrm{m}^{2}$.

\section{References}

BROOM D.M. (1991): Animal welfare: concepts and measurement. J. Animal Scince, 69, 4167-4175.

Council of the European Union (2007): Council Directive 2007/43/CE http://ec.europa.eu/food/animal/welfare/farm/broilers_en.htm

CRAVENER T.L., ROUSH W.B., MASHALY M.M. (1992): Broiler production under varying population densities. Poultry Science, 71, 427-433.

DOZIER W.A., THAXTON J.P., BRANTON S.L., MORGAN G.W., MILES D.M., ROUSH W.B., LOTT B.D., VIZZIER-THAXTON Y. (2005): Stocking 
Density on Growth Performance and Processing Yields of Heavy Broilers. Poultry Science, 84, 1332-1338.

DOZIER W.A., THAXTON J.P., PURSWELL J.L., OLANREWAJU H.A., BRANTON S.L., ROUSH W. B. (2006): Stocking Density Effects on Male Broilers Grown to 1,8 Kilograms of Body Weight. Poultry Science, 85, 344-351.

ELWINGER K. (1995): Broiler production under varying population densities-A field study. Archiv für Geflügelkunde, 59, 4, 209-215.

GYLES N.R., KAN J., SMITH R.M. (1962): The heritability of breast blister condition and breast feather coverage in a White Rock broiler strain. Poultry Science, 42, 13-17.

HRISTOV S., VUČINIĆ M., RELIĆ R., STANKOVIĆ B. (2006): Uslovi gajenja, dobrobit i ponašanje farmskih životinja. Biotehnologija u stočarstvu, 22, posebno izdanje, 73-84.

KESTIN S.C., KNOWLES T.G, TINCH A.E., GREGORY N.G. (1992): Prevalence of leg weakness in broiler chickens and relationship with genotype. Veterinary Record, 131, 190-194.

LEESON S., WALSH T. (2004): Feathering in commercial poultry II. Factors influencing feather growth and feather loss. World's Poultry Science Journal, 60, 52-63.

MENDES A.A., GARCIA R.G., IMEIDA I.C.L.A., MOREIRA J. (2004): Effect of stocking densities and season on performance, environmental and thermoregulatory parameters and carcass yield of broiler chickens. XXII World's Poultry Congress, Istanbul-Turkey, 8-13 June 2004, Book of abstracts, 417 (Fulltext CD).

PERIC L., NOLLET L., MILOSEVIC N., ZIKIC D. (2007): Effect of Bioplex and Sel-Plex substituting inorganic trace mineral sources on performance of broilers. Archiv für Geflügelkunde, 71, 3, 122-129.

SUNDRUM A. (2001): Organic livestock farming - a critical review. Livestock Production Science, 67, 3, 207-215.

ŠKRBIĆ Z. (2007): Efekti gustine naseljenosti i svetlosnog programa na proizvodne i klanične osobine brojlerskih pilića različitog genotipa. Doktorska disertacija. Poljoprivredni fakultet, Beograd.

ŠKRBIĆ Z., PAVLOVSKI Z., LUKIĆ M., PERIĆ L., MILOŠEVIĆ N. (2009):The Effect of Stocking Density on Certain Broiler Welfare Parameters. Biotechnology in Animal Husbandry, 25, 1-2, 11-21.

THOMAS D.G., RAVINDRAN V., THOMAS D.V., CAMDEN B.J., COTTAM Y.H., MOREL P.C.H., COOK C.J. (2004): Influence of stocking density on the performance, carcass characteristics and selected welfare indicators of broiler chickens. New Zealand Veterinary Journal, 52, 76-81.

Zakon o dobrobiti životinja. Službeni glasnik RS 41/09 